\title{
The 21st century epidemic: infections as inductors of neuro-degeneration associated with Alzheimer's Disease
}

\author{
Federico Licastro ${ }^{1,2^{*}}$, Ilaria Carbone ${ }^{1}$, Elena Raschi ${ }^{1}$ and Elisa Porcellini ${ }^{1}$
}

\begin{abstract}
Alzheimer's disease (AD) is a complex disease resulting in neurodegeneration and cognitive impairment. Investigations on environmental factors implicated in AD are scarce and the etiology of the disease remains up to now obscure. The disease's pathogenesis may be multi-factorial and different etiological factors may converge during aging and induce an activation of brain microglia and macrophages. This microglia priming will result in chronic neuro-inflammation under chronic antigen activation. Infective agents may prime and drive iper-activation of microglia and be partially responsible of the induction of brain inflammation and decline of cognitive performances. Age-associated immune dis-functions induced by chronic sub-clinical infections appear to substantially contribute to the appearance of neuro-inflammation in the elderly. Individual predisposition to less efficient immune responses is another relevant factor contributing to impaired regulation of inflammatory responses and accelerated cognitive decline. Life-long virus infection may play a pivotal role in activating peripheral and central inflammatory responses and in turn contributing to increased cognitive impairment in preclinical and clinical AD.
\end{abstract}

Keywords: Alzheimer's disease, Herpes virus latency, Peripheral inflammation, Neuro-inflammation, Inflammatory markers and cognitive decline

\section{Introduction}

\section{Alzheimer dementia type and infections}

Alzheimer's disease (AD) is a progressive neurodegenerative disorder and the most common cause of dementia. According to the World Health Organization, nearly 35.6 millions of people worldwide currently may suffer from dementia. The disease affects people in all countries with more than half patients living in low- and middle-income countries and by 2050, this figure is likely to rise to more than $70 \%[1]$.

Because of the urgency for effective preventive and therapeutic measures, extensive research has focused on pathogenetic mechanisms of $\mathrm{AD}$, however, up to now, no therapy has been found.

Some neuro-pathological alterations such as amyloid deposition and neurofibrillary tangles (NFTs) are almost

\footnotetext{
* Correspondence: federico.licastro@unibo.it

'Department of Experimental, Diagnostic and Specialty Medicine, School of Medicine, University of Bologna, Bologna 40100, Italy

${ }^{2}$ Laboratory of Immunopathology and Immunogenetics, Department of Experimental, Diagnostic and Specialty Medicine, School of Medicine, University of Bologna, Via S. Giacomo 14, 40126 Bologna, Italy
}

always found in the brain after the autopsy examination of patients who suffered dementia. Therefore, these alterations have been suggested to be causative of the disease $[2,3]$. However, these pathological alterations are also present in the brain of elderly who died without the clinical presentation of $\mathrm{AD}$ [4] and the notion that amyloid deposition and other proteinaceous alterations might be causative of $\mathrm{AD}$ is made uncertain by these observations.

Amyloid beta peptide (Abeta) is the major component of amyloid deposits in AD brains [2] and derives from the processing of a highly conserved membrane protein named amyloid precursor protein (APP) [5]. The physiological function of APP and its biological role remain unclear [6]. However, few years ago a role as antimicrobial defensive factor for A-beta peptide has been suggested [7]. A recent investigation confirmed that the A-beta peptides showed a relevant anti-virus activity in vitro and suggested that these peptides may have a defensive role against the influenza virus [8]. 


\section{Review}

\section{Herpes family and dementia}

In our previous publications $[9,10]$ we discussed genetic data from four genome wide association (GWA) studies on $A D$ [11-14]. From these investigations a set of singlenucleotide polymorphisms (SNPs) associated with AD emerged and we suggested that the concomitant presence of these SNPs might result in a genetic signature predisposing to $\mathrm{AD}$, via complex and diverse mechanisms, each contributing to an increase of individual susceptibility to herpes virus infection $[9,10]$.

A viral etiology, especially involving herpes virus in $\mathrm{AD}$, has been already proposed and most investigations have shown an association of herpes simplex virus type 1 (HSV-1) with AD [15-19].

HSV-1 is a ubiquitous virus that affects more than $80 \%$ of people over 65 worldwide. It is a neurotropic double-stranded DNA virus that primarily infects epithelial cells of oral and nasal mucosa. Here virus undergoes lytic replication; the newly produced viral particles may enter sensory neurons and, by axonal transport, reach the trigeminal ganglion where usually establishes a latent infection. The virus undergoes periodic reactivation cycles in which the newly formed viral particles are transported back to the site of primary infection through the sensory neurons, causing the well-known clinical lesions (i.e., cold sores and blisters). However, the bipolar trigeminal ganglion neurons also project to the trigeminal nuclei located in the brainstem. From here, neurons project to the thalamus to finally reach the sensory cortex. This is the path through which the reactivated virus may reach the central nervous system (CNS), where it may cause acute neurological disorders like encephalitis [herpes simplex encephalitis (HSE)] or a mild, clinically asymptomatic, infection, or establish life-long latent infection [20].

Recent reports showed a significant association of HSV-1 infection with AD risk in a longitudinal nested study from Sweden [21]. A reactivation of HSV-1 infection assessed by increased serum levels of specific anti-HSV-1 antibodies was found associated with an increased AD risk in a longitudinal study on 3432 elderly [21]. Another study from Italy reported that elevated serum HSV-1 antibody titers correlated with cortical grey matter volume as assessed by MRI [22].

It is interesting to note that others herpes viruses share the ability to become latent in the infected host and eventually latently infect neurons.

On the other hand, investigations focused on different viruses of the herpes family, such as human cytomegalovirus (CMV), Epstein-Barr virus (EBV) or human herpes virus 6 (HHV-6) in $\mathrm{AD}$ are limited.

CMV is ubiquitously distributed in human population and the most frequent brain infection in immune compromised patients or in infants with congenital virus transmission [23]. Postnatal acute peripheral CMV infection is usually asymptomatic, but once established, the virus remains latent in blood monocytes [24].

CMV has also been associated with other chronic diseases of aging, including cardiovascular disease, cognitive decline and cancer. The specific mechanisms responsible for these associations have not been fully understood, but they are likely to have an immune and inflammatory component [25].

The sero-conversion to positive CMV may vary over the years, ranging between 0.5 to $1.5 \%$ per year. It has been suggested that CMV is responsible for the ageassociated immune changes in the elderly which lead to a reduction in the number of naïve $\mathrm{T}$ cells $[26,27]$.

An increased rate of cognitive decline over a four year period in subjects with elevated CMV antibody levels has also been reported [28]. Previous work upon brain frontal and temporal cortex samples found that both $\mathrm{AD}$ patients and elderly healthy subjects were positive for CMV with no statistically significant difference between the two groups [29]. CMV was found in the brain of a greater proportion of patients with vascular dementia than normal elderly; these findings suggested a role for this virus in the disease [30].

Our recent work showed that increased CMV antibody levels were present in the elderly who developed clinical AD during a five years follow up [31].

Findings from another investigation reported that CMV infection doubled the risk of developing AD in a longitudinal follow up of 849 participants from USA [32].

EBV infects more than $95 \%$ of human beings within the first years of life. The virus causes acute infectious mononucleosis in a minority of immune competent subjects, while the majority develops a lifelong asymptomatic infection and the virus remains latent in Blymphocytes. EBV is also involved in the development of several diseases such as Burkitt lymphoma, Hodgkin lymphoma and nasopharyngeal carcinoma [33].

Moreover, EBV seems to be involved in the pathogenesis of various neurological diseases, such as encephalitis, neuritis, myelitis, cerebellitis, acute disseminated encephalomyelitis, or central nervous system (CNS) lymphoma in patients with the immunodeficiency virus (HIV) infection [34] and multiple sclerosis [35].

Recently our findings showed an association of peripheral blood positivity for EBV genome and AD [31]. Moreover, elevated levels of EBV specific antibodies were associated with an increased AD risk [31].

HHV-6 is a neurotropic virus and has been associated with multiple neurological diseases including seizures, encephalitis, mesial temporal lobe epilepsy and multiple sclerosis [36]. 
HHV-6 has been found in a higher proportion of AD brains than age-matched control (CTR) brains [29]. However, these findings were not confirmed by another investigation [37] that reported a higher value of HHV-6 level in CTR brains.

Our findings showed an elevated positivity in brains and peripheral blood for HHV-6 genome in AD [31]. Increased sero-positivity was also associated with clinical diagnosis of AD [31].

The sero-positivity to CMV, EBV or HHV-6 is very high worldwide and viruses of the herpes family are largely and commonly present in the elderly.

It is of interest to note that the immune response of the host to infections undergoes age-dependent changes following a process called immune senescence. Immune senescence may lead to an increased susceptibility of older adults to develop, not only infectious disease, but also Alzheimer's disease, osteoporosis, cancer and autoimmunity [38].

\section{The impact of persistent virus infections upon the impairment of immune responses in the elderly}

The aging of the immune system is a continuous and dynamic process and it might be secondary to mechanisms activated by the response to the pathogen individual internal milieu [39].

No all immune responses show the same rate of aging or senescence. In fact, innate immunity seems to be preserved along the years, while adaptive immune responses progressively decline with age [40].

Recent investigations focused on immune senescence suggested that the progressive decline of immune defense efficiency might be an adaptation mechanism to the microorganism exposure experienced by the aging organism over the life time [41].

A pivotal question, therefore, is: what is the cause of the progressive senescence of the adaptive immune responses in the elderly?

Longitudinal investigations showed that $\mathrm{T}$ cell phenotypes and functions progressively change with advancing age and these populations in the peripheral blood of the elderly consist of super specialized CD4 positive and CD8 positive $\mathrm{T}$ lymphocyte populations $[42,43]$. These $\mathrm{T}$ cell populations appeared to be immunologically exhausted according to some Authors [43].

It is interesting to note that the common presence of CMV sero-positivity in the elderly is associated to an age related increase of specialized CD8T cells specific for CMV antigens [44]. Moreover, other chronic virus infections also contribute to shape the immune phenotype during aging and their collective immune pressure changes the representation of peripheral $\mathrm{T}$ cell populations in the elderly [41].
Naïve $\mathrm{T}$ cells are positive for the following surface markers: CCR7, CD45RA, CD27 and CD28. Central memory $\mathrm{T}$ cells $(\mathrm{CM})$ are positive for CCR7, CD27 and CD28 markers. Memory T effector cells (EM) are lightly positive for CD27 and CD28. Finally, the terminal differentiated memory $\mathrm{T}$ cells (TEMRA) are positive for CD45RA and KLRG-1 surface markers [41].

A summary of the immune impact of virus infection on human circulating $\mathrm{T}$ cells representation is reported in Table 1 [41].

EBV, varicella zoster virus and HSV-1 have a severe impact on immune system and contribute to reshape the immune phenotype in the old person by inducing a persistent antigenic stimulation [45].

For instance, viruses of the herpes family infect the majority of human population since childhood and by frequent cycle of reactivation and latency constantly challenge the immune response and drive the accumulation of memory $\mathrm{T}$ cells. Therefore, the continuous antigen stimulation induced by chronic infectious microorganisms activates a peripheral chronic inflammatory response that progressively induces the loss of naïve and inducible CD4 and CD8 positive $\mathrm{T}$ cells and the accumulation of memory T cell populations.

The change in the percentage and the absolute number of regulatory $\mathrm{T}$ cells (Tregs) plays a peculiar relevance in the age dependent re-shaping in the human immune phenotype. In fact, a progressive loss of inducible Tregs and an increment of naturally occurring Tregs characterized $\mathrm{T}$ cell population change in the elderly, as shown in Figure 1 [41].

We can conclude that during aging a constant antigen pressure is partially responsible for the age associated immune decline.

In fact, with advancing age the adaptive immune response, the immune diversity and the plasticity of immune responses decline because of the immune reserve decrease induced by antigen load of chronic infections. This process is represented in Figure 2 [41].

Chronic infections represent important environmental factors able to induce a re-shaping of the immune system by antigen load during aging. Chronic sub-clinical viral infections such as those caused by herpes viruses with their characteristic cycles of latency and reactivation may play a relevant role. These viruses indeed infect a large proportion of human population and the immune system is not able to completely eradicate the viruses.

Moreover, as is the case of CMV, the adaptive immune responses pay a high price to maintain the virus in the latent form, since the immune resources involved in anti-virus defensive mechanisms are elevated. In fact, in the elderly as many as $50 \%$ of cytotoxic CD8 positive T cells and $30 \%$ of the helper CD4 T cells can be positive 
Table 1 Effects of persistent virus infections upon the different $\mathrm{T}$ cell populations in the peripheral blood of young and old subjects [modified from Fülöp et al [41]

\begin{tabular}{|c|c|c|c|c|c|c|}
\hline & CMV & HBV & EBV & VZV & HSV-1 & HHV-6 \\
\hline Expansion & +++ & + & + & - & - & $?$ \\
\hline Viral load & $+/-$ & $+/-$ & $+/-$ & $+/-$ & $+/-$ & $+/-$ \\
\hline Reactivation & $?$ & $?$ & $?$ & $+/-$ & $+/-$ & - \\
\hline Immune phenotype & TEMRA & EM & EM & CM/EM & EM & TREG \\
\hline Immunological aging & ++++ & + & ++ & - & - & - \\
\hline Clinical impact in young & Moderate & Mild & Moderate & Mild & Mild & Moderate/Severe \\
\hline Clinical impact in elderly & Moderate & Mild & Moderate & Severe & Mild & $?$ \\
\hline
\end{tabular}

$\mathrm{CM}=$ central memory cells; $\mathrm{EM}=$ effector memory cells; TEMRA = terminally differentiated memory cells re-expressing CD45RA.

$?=$ data not available.

for this virus antigens. Naïve and memory $\mathrm{T}$ cells with different antigen specificity proportionally and concomitantly decrease.

Decreased protection after vaccination, increased risk of cardiovascular diseases and type 2 diabetes are the clinical consequences of the immune system re-shaping in the elderly. All these conditions are associated with increased age-associated peripheral inflammation.

\section{Classical and alternatively activated microglia in AD}

It has been known for some decades that tissue macrophages may be differently activated. These two stages of metabolic activation have been defined M1 and M2 and they can be identified by up-regulation of membrane markers after stimulation by different factors.

M1 macrophages show a pro inflammatory function, whilst M2 have anti inflammatory activity.

IFN-gamma produced by $\mathrm{T}$ helper-1 lymphocytes induces the M1 activation state and these macrophages produce high levels of TNF-alpha and iNOS [46].

M2 macrophages, also called alternatively activated, do not release NO, are not cytotoxic, and are activated by $\mathrm{T}$ helper- 2 derived interleukins, such as IL-4, IL-5 and IL-
13. M2 are considered regulatory macrophages, since they inhibit the release of several cytokines from other cells of the immune system [47].

As far as AD neurodegeneration is concerned, there is a consensus suggesting that the inflammatory milieu associated with the neuro-inflammation inhibits the microglia phagocytosis [48]. Moreover, in the PS1M146L/APP751SL mouse model of $\mathrm{AD}$ an age dependent switch of brain microglia from the alternative to the classical phenotype was observed [49].

However, other investigations on AD animal models reported that brain microglia over-expressed markers of the alternatively activated phenotype [50,48].

Under normal conditions, few activated $\mathrm{T}$ cells gain entry to the brain and are involved in immune surveillance. However, infiltration of a significant number of $\mathrm{T}$ cells occurs in brain disease or after brain injury. The consequences of $\mathrm{T}$ cell infiltration may play a neurodestructive or neuroprotective role in different disease animal models [48]. A recent paper reviewed this topic concluding that brain infiltrating $\mathrm{T}$ cells regulate microglia activation by releasing IFN-gamma and, therefore, driving neurodegenerative processes associated with $\mathrm{AD}[48]$.

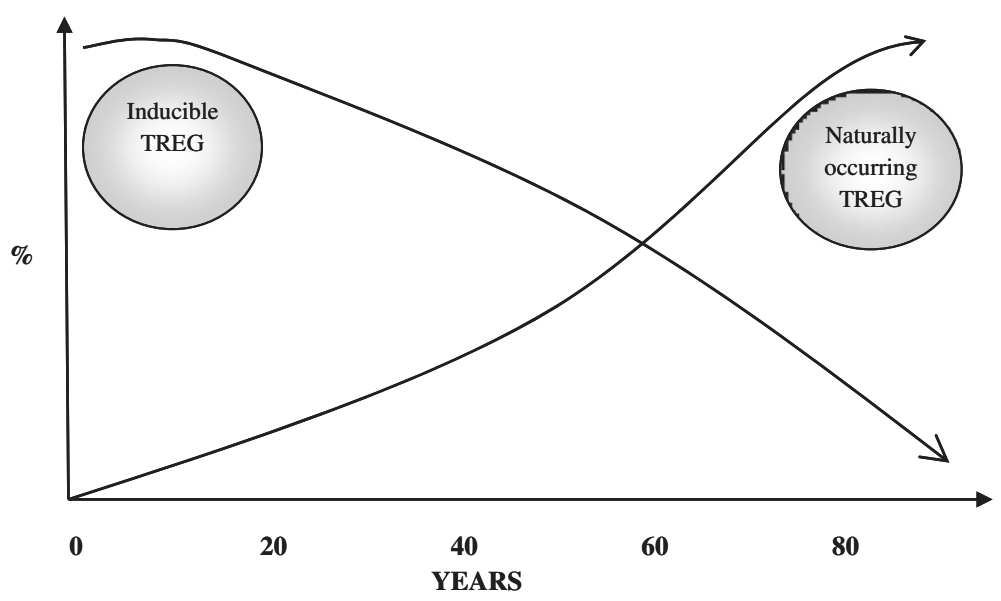

Figure 1 The change in the percentage of regulatory T cells (Tregs) with the age [modified from Fülöp et al. [41]. 




Figure $\mathbf{2}$ The decline of the immune diversity and plasticity with advancing age in relation to a decrement of immune reserve induced by antigen load of chronic infections [modified from Fülöp et al. [41].

Microglia activation in pre-clinical and clinical AD by neuro-imaging techniques has been reported [51,52].

A defective resolution of inflammatory state has been recently found in the brain of patients with $\mathrm{AD}$ and this impairment correlated with cognitive function [53]. Moreover, elevated levels of CNS inflammation and CSF inflammatory markers have been also reported in preclinical stages of AD [54].

In conclusion, brain microglia from AD patients is activated and release several cytokines that induce neuroinflammation.

\section{Peripheral inflammation and neurodegeneration in AD}

As above discussed, inflammatory responses are present in the brain of patients with $\mathrm{AD}$ and activated microglia cells are a pathological marker of the disease [55].

However, it is important to note that several observations have also shown that increased peripheral inflammatory responses are detectable in patients with $\mathrm{AD}$ [56]. For instance, increased levels of certain cytokines and acute phase proteins are well detectable in the blood of AD [57]. Therefore, peripheral inflammatory state is higher in AD patients than in cognitively healthy elderly $[58,56]$.

It is likely that, as the neurodegenerative processes progress in the brain, a concomitant increased peripheral dis-regulation of immune responses increases.

This notion is supported by several observations. For instance, a recent report from a study originally designed to investigate of osteoporotic fractures showed that a significant change in peripheral inflammatory markers was present in the oldest-old women and correlated with cognitive decline [59].

A recent overview of the topic concluded that published data were conflicting; however, some cytokines showed a steady increase during progression from mild cognitive decline (MCI) to AD [60].

An association between late life depression, $\mathrm{MCI}$ and $\mathrm{AD}$ is well documented and an interesting paper suggested that peripheral inflammation might be the missing link in these different conditions [61].

Increased serum levels of inflammatory factors have been reported also in MCI with different genetic background from China [62].

A recent report by applying sophisticated statistical analysis to disclose the relationship between immunological and oxidative stress markers in $\mathrm{AD}$ and $\mathrm{MCI}$, showed that a global immune deficit in $\mathrm{MCI}$ and $\mathrm{AD}$ was detectable [63]. In fact, both adaptive and innate immunity were peripherally defective. A widespread immune deficit, as suggested in the study, is conceivable to be a concomitant factor in disease progression both for inadequate control of local inflammation and for an insufficient supply in repairing factors [63].

We can conclude that peripheral inflammation is indeed present in early stage of AD and is higher than that observed during non pathological aging [60]. Moreover, an altered inflammatory regulation is also present in $\mathrm{MCI}$ and correlate with the progression to AD [60].

The missing link between central neuro-inflammation and peripheral inflammatory state: infectious factors

It has been shown from the Rush Alzheimer's Disease Center Religious Order that CMV serum levels were associated with NFT in the autopsy brains [64]. It is of interest that the percentages of senescent CD4 and CD8 $\mathrm{T}$ cells were higher in CMV sero-positive than in seronegative subjects and marginally associated with $\mathrm{AD}$ diagnosis. Moreover, Lurain and co-workers reported 
that the infection of human fibroblasts by CMV induced the expression of amyloid beta peptides [64].

Therefore, a more stringent link may bind peripheral and central inflammatory responses in AD.

This link may consist of chronic infections by microorganisms, such as viruses, that are able to constantly impair immune responses.

\section{Bacterial infection, cognitive decline and dementia}

It is important to keep in mind that several pathogens may show the potential ability to dis-regulate the immune responses.

In fact, virus infections are not the unique challenge for the aging immune system. Persistent low level bacterial infections also play a role in inducing chronic inflammation in the elderly. Specifically, oral microbiome and oral infections have been recently reviewed as potential causes of blood brain barrier (BBB) disruption and brain inflammation; these pathogens may also infect the brain via trigeminal and/or olfactory nerves [65].

Chronic inflammation in periodontal disease, for example, has been suggested as a potential risk factor in Alzheimer's disease [66]. Periodontal disease is a peripheral, chronic infection, which elicits a systemic inflammatory response [67]. The chronic trickling of Gram negative, anaerobic periodontal bacteria into the systemic bloodstream result in elevated levels of various inflammatory mediators in the serum of periodontitis patients. Some inflammatory mediators associated with periodontal disease, e.g. C Reactive Protein (CRP), Interleukin 6 (IL 6), Interleukin 1(IL 1 1 ), and TNF- $\alpha$ have been suggested to increase the risk of cognitive decline and/or Alzheimer's disease [66].

In the study of Sparks Stein P et al., both the AD and MCI subjects demonstrated significant elevations in antibody to $P$. intermedia and $F$. nucleatum at baseline, prior to diagnosis of the neurological changes. Additionally, the $\mathrm{AD}$ subjects expressed significantly elevated antibody to $T$. denticola, and $P$. gingivalis at baseline. Interestingly, the control group also showed antibody levels higher than healthy values for four of the seven bacteria (A. actinomycetemcomitans, C. rectus, T. forsythia and $P$ gingivalis) with three of the four at levels consistent with chronic periodontal disease. Regardless, the levels of antibodies in the control group were significantly lower than the levels of those who converted to $\mathrm{AD}$ at baseline for five of the seven bacteria studied [66]. Whether oral bacteria themselves or endotoxins (e.g., LPS) released by them gain access to the brain, the net result is likely to be microglial activation. Microglial activation is a well-recognized feature of $\mathrm{AD}$ and results in the increased production of proinflammatory cytokines such as TNF and IL1 $\beta$. This could explain why levels of, for example, TNF in the cerebrospinal fluid of $\mathrm{AD}$ patients reach such high levels, 25-fold that of controls. Prolonged exposure to high concentrations of TNF weakens the protective $\mathrm{BBB}$ making it more permeable to ingress of bacteria or endotoxins [65].

Chronic low level inflammation induced by sub clinical infections may therefore play a pivotal role in directly or indirectly activate brain immune responses and neuro-inflammation.

\section{Host genetic makeup, immune responses and dementia}

However, it is also relevant how the host responds to these microorganisms. In fact, the individual genetic background plays a pivotal role in the maintenance of the chronic inflammation both in the brain and in the peripheral tissues.

In this context, as already mentioned, GWA studies in AD showed that several immune factors were associated with increased risk of the disease. However, each single immune gene showed a low odd ratio $(\mathrm{OR}<1.7)$ of association with $\mathrm{AD}$.

The only exception was the allele 4 of the APOE gene that was confirmed to have a high OR with AD. APOE gene also appears to be involved in chronic infections and it is important to note that the APOE gene is a well known susceptibility factor for several virus infections [68-70]. Besides, ApoE4 compromises the integrity of the BBB by activating the cyclophilin A matrix metalloproteinase MMP-9 pathway [71]. This is particularly important if the penetration of bacteria or LPS into the brain is involved in the initiation or progression of $\mathrm{AD}$ [65].

The weak association of immune genes with $\mathrm{AD}$ can be simply explained, as no immune factor is the cause of the disease. Nevertheless, the concomitant presence of several genetic factors in the same individual might show a more sound association and individual infection susceptibility may be affected by the concomitant presence of alleles resulting in decreased immune efficiency $[9,10]$.

As infections appear to play a role, the link between a given pathogen and the host susceptibility to its infectivity might be one missing link in the pathogenesis of cognitive decline progression to clinical $\mathrm{AD}$.

Our recent findings showed that polymorphisms in genes regulating antiviral responses are differently distributed in $\mathrm{AD}$ and influence a differential positivity to EBV and HHV-6 genomes in the elderly (data submitted). Moreover, risk alleles were increased in elderly progressing to $\mathrm{AD}$ (data submitted). These observations reinforce the notion that individual genetic background plays a role in the progression of cognitive impairment by influencing the efficiency of immune responses to persistent parasites.

Different immune genetic makeup will weaken the defensive mechanisms against few pathogens. This immunological weakness, however, will show relevant effects over 
the life span time by interfering with the defensive mechanisms against other pathogens able to directly infect the brain or against microorganisms able to produce toxins which, in turn, impair the BBB and/or kill neurons. All these mechanisms may have deleterious effects on cognitive performances during aging.

\section{Conclusions}

$\mathrm{AD}$ is a multi-factorial diseases, which shows different etiological and pathogenetic factors. Several different pathogens, both viruses and bacteria, may play a role in triggering ill controlled inflammatory responses and directly or indirectly activate neuro-inflammation. An important role in brain defenses against microorganisms is played by APP and its peptides. However, in subjects who will develop $\mathrm{AD}$ this protective mechanism appear to be unsuccessful. Besides, the pathogen induced reshaping of adaptive immune responses has deep consequences in the altered regulation of both peripheral and central immune defensive mechanisms.

Individual susceptibility to different pathogens under the control of personal genetic background plays a secondary but not marginal role in the unsuccessful regulation of defensive immune responses and poorly controlled inflammation. Therefore, the activation of persistent peripheral inflammation has detrimental effect upon the brain in genetically susceptible individuals.

If this view of the disease will be shared by an increasing number of scientists and experimentally and clinically verified, several new therapeutic interventions may open for AD patients. Successful treatment of chronic infections is a challenging but mandatory goal to improve the quality of life in the elderly.

\section{Competing interests}

The authors declare that they have no competing interests.

\section{Authors' contributions}

EP and IC contributed to search Medline for virus association in AD, ER contributed to search Medline for bacterial association in $A D$ and performed figures and table's setup, FL designed the hypothesis, supervised Medlines and the final version of the manuscript. All Authors drafted the manuscript and approved the final manuscript.

\section{Acknowledgements}

Research supported by grants from Italian Ministry for University and Research, Italy, CARISBO Foundation Bologna, Italy, and BRACCO

Pharmaceutics Milano, Italy.

Received: 31 October 2014 Accepted: 22 November 2014 Published online: 05 December 2014

\section{References}

1. World Health Organization: [http://www.who.int/mediacentre/news/ releases/2012/dementia_20120411/en/]

2. Terry RD: Neuropathological changes in Alzheimer disease. Prog Brain Res 1994, 101:383-390.

3. Trojanowski JQ, Clark CM, Schmidt ML, Arnold SE, Lee VM: Strategies for improving the postmortem neuropathological diagnosis of Alzheimer's disease. Neurobiol Aging 1997, 18(4 Suppl):S75-S79.
4. Elman JA, Oh H, Madison CM, Baker SL, Vogel JW, Marks SM, Crowley S, O'Neil JP, Jagust WJ: Neural compensation in older people with brain amyloid- $\beta$ deposition. Nat Neurosci 2014, 17(10):1316-1318.

5. O'Brien RJ, Wong PC: Amyloid precursor protein processing and Alzheimer's disease. Annu Rev Neurosci 2011, 34:185-204.

6. Nalivaeva NN, Turner AJ: The amyloid precursor protein: a biochemical enigma in brain development, function and disease. FEBS Lett 2013, 587(13):2046-2054.

7. Soscia SJ, Kirby JE, Washicosky KJ, Tucker SM, Ingelsson M, Hyman B, Burton MA, Goldstein LE, Duong S, Tanzi RE, Moir RD: The Alzheimer's disease-associated amyloid beta-protein is an antimicrobial peptide. PLoS One 2010, 5(3):e9505.

8. White MR, Kandel R, Tripathi S, Condon D, Qi L, Taubenberger J, Hartshorn KL: Alzheimer's associated $\beta$-amyloid protein inhibits influenza $A$ virus and modulates viral interactions with phagocytes. PLoS One 2014, 9(7):e101364.

9. Porcellini E, Carbone I, lanni M, Licastro F: Alzheimer's disease gene signature says: beware of brain viral infections. Immun Ageing 2010, 7:16

10. Licastro F, Carbone I, lanni M, Porcellini E: Gene signature in Alzheimer's disease and environmental factors: the virus chronicle. J Alzheimers Dis 2011, 27(4):809-817.

11. Lambert JC, Heath S, Even G, Campion D, Sleegers K, Hiltunen M, Combarros O, Zelenika D, Bullido MJ, Tavernier B, Letenneur L, Bettens K, Berr C, Pasquier F, Fiévet N, Barberger-Gateau P, Engelborghs S, De Deyn P, Mateo I, Franck A, Helisalmi S, Porcellini E, Hanon O, European Alzheimer's Disease Initiative Investigators, de Pancorbo MM, Lendon C, Dufouil C, Jaillard C, Leveillard T, Alvarez V, et al: Genome-wide association study identities variants at CLU and CR1 associated with Alzheimer's disease. Nat Genet 2009, 41:1094-1099.

12. Harold D, Abraham R, Hollingworth P, Sims R, Gerrish A, Hamshere ML, Pahwa JS, Moskvina V, Dowzell K, Williams A, Jones N, Thomas C, Stretton A, Morgan AR, Lovestone S, Powell J, Proitsi P, Lupton MK, Brayne C, Rubinsztein DC, Gill M, Lawlor B, Lynch A, Morgan K, Brown KS, Passmore PA, Craig D, McGuinness B, Todd S, Holmes C, et al: Genome-wide association study identities variants at CLU and PICALM associated with Alzheimer's disease. Nat Genet 2009, 41:1088-1093.

13. Hollingworth P, Harold D, Sims R, Gerrish A, Lambert JC, Carrasquillo MM, Abraham R, Hamshere ML, Pahwa JS, Moskvina V, Dowzell K, Jones N, Stretton A, Thomas C, Richards A, Ivanov D, Widdowson C, Chapman J, Lovestone S, Powell J, Proitsi P, Lupton MK, Brayne C, Rubinsztein DC, Gill M, Lawlor B, Lynch A, Brown KS, Passmore PA, Craig D, et al: Common variants at ABCA7, MS4A6A/MS4A4E, EPHA1, CD33 and CD2AP are associated with Alzheimer's disease. Nat Genet 2011, 43:429-435.

14. Naj AC, Jun G, Beecham GW, Wang LS, Vardarajan BN, Buros J, Gallins PJ, Buxbaum JD, Janvik GP, Crane PK, Larson EB, Bird TD, Boevem BF, Graff-Radford NR, De Jager PL, Evans D, Schneider JA, Carrasquillo MM, Ertekin-Taner N, Younkin SG, Cruchaga C, Kauwe JS, Nowotny P, Kramer P, Hardy J, Huentelman MJ, Myers AJ, Barmada MM, Demirci FY, Baldwin CT, et al: Common variants at MS4A4/MS4A6E, CD2AP, CD33 and EPHA1 are associated with late-onset Alzheimer's disease. Nat Genet 2011, 43:436-441.

15. Wozniak MA, Mee AP, Itzhaki RF: Herpes simplex virus type 1 DNA is located within Alzheimer's disease amyloid plaques. J Pathol 2009, 217(1):131-138.

16. Itzhaki RF, Wozniak MA: Herpes simplex virus type 1 in Alzheimer's disease: the enemy within. J Alzheimers Dis 2008, 13:393-405.

17. Carter $\mathrm{CJ}$ : Interactions between the products of the herpes simplex genome and Alzheimer's disease susceptibility genes: relevance to pathological-signalling cascades. Neurochem Int 2008, 52:920-934.

18. Burgos JS, Ramirez C, Sastre I, Valdivieso F: Effect of apolipoprotein E on the cerebral load of latent herpes simplex virus type 1 DNA. J Virol 2006 80:5383-5387.

19. Mori I, Kimura Y, Naiki H, Matsubara R, Takeuchi T, Yokochi T, Nishiyama Y: Reactivation of HSV-1 in the brain of patients with familial Alzheimer's disease. J Med Virol 2004, 73:605-611.

20. Piacentini R, De Chiara G, Li Puma DD, Ripoli C, Marcocci ME, Garaci E, Palamara AT, Grassi C: HSV-1 and Alzheimer's disease: more than a hypothesis. Front Pharmacol 2014, 5:97.

21. Lövheim H, Gilthorpe J, Adolfsson R, Nilsson LG, Elgh F: Reactivated herpes simplex infection increases the risk of Alzheimer's disease. Alzheimers Dement 2014, S1552-5260(14):02421-02422.

22. Mancuso R1, Baglio F, Cabinio M, Calabrese E, Hernis A, Nemni R, Clerici M: Titers of herpes simplex virus type 1 antibodies positively correlate with 
grey matter volumes in Alzheimer's disease. J Alzheimers Dis 2014, 38(4):741-745.

23. Tsutsui Y, Kosugi I, Kawasaki H, Arai Y, Han GP, Li L, Kaneta M: Roles of neural stem progenitor cells in cytomegalovirus infection of the brain in mouse models. Pathol Int 2008, 58(5):257-267.

24. Pawelec G, Derhovanessian E, Larbi A, Strindhall J, Wikby A: Cytomegalovirus and human immunosenescence. Rev Med Virol 2009, 19:47-56.

25. Simanek AM, Dowd JB, Pawelec G, Melzer D, Dutta A, Aiello AE: Seropositivity to cytomegalovirus, inflammation, all-cause and cardiovascular disease-related mortality in the United States. PLoS One 2011, 17(6(2)):e16103.

26. Koch S, Solana R, Dela Rosa O, Pawelec G: Human cytomegalovirus infection and T cell immunosenescence: a mini review. Mech Ageing Dev 2006, 127(6):538-543.

27. Rymkiewicz PD, Heng YX, Vasudev A, Larbi A: The immune system in the aging human. Immunol Res 2012, 53(1-3):235-250.

28. Aiello AE, Haan M, Blythe L, Moore K, Gonzalez JM, Jagust W: The influence of latent viral infection on rate of cognitive decline over 4 years. $J \mathrm{Am}$ Geriatr Soc 2006, 54(7):1046-1054

29. Lin WR, Wozniak MA, Cooper RJ, Wilcock GK, Itzhaki RF: Herpesviruses in brain and Alzheimer's disease. J Pathol 2002, 197(3):395-402.

30. Itzhaki RF, Wozniak MA, Appelt DM, Balin BJ: Infiltration of the brain by pathogens causes Alzheimer's disease. Neurobiol Aging 2004, 25(5):619-627.

31. Carbone I, Lazzarotto T, lanni M, Porcellini E, Forti P, Masliah E, Gabrielli L, Licastro F: Herpes virus in Alzheimer's disease: relation to progression of the disease. Neurobiol Aging 2014, 35(1):122-129.

32. Barnes LL, Capuano AW, Aiello AE, Turner AD, Yolken RH, Torrey EF, Bennett DA: Cytomegalovirus infection and risk of Alzheimer disease in older black and white individuals. J Infect Dis 2014, pii:jiu437.

33. Kutok JL, Wang F: Spectrum of Epstein-Barr virus-associated diseases. Annu Rev Pathol 2006, 1:375-404.

34. Kleines M, Schiefer J, Stienen A, Blaum M, Ritter K, Häusler M: Expanding the spectrum of neurological disease associated with Epstein-Barr virus activity. Eur J Clin Microbiol Infect Dis 2011, 30(12):1561-1569.

35. Lassmann H, Niedobitek G, Aloisi F, Middeldorp JM, NeuroproMiSe EBV Working Group: Epstein-barr virus in the multiple sclerosis brain: a controversial issue-report on a focused workshop held in the centre for brain research of the medical university of Vienna, Austria. Brain 2011, 134(Pt 9):2772-2786.

36. Yao K, Crawford JR, Komaroff AL, Ablashi DV, Jacobson S: Review part 2: Human herpesvirus- 6 in central nervous system diseases. J Med Virol 2010, 82(10):1669-1678.

37. Hemling N, Röyttä M, Rinne J, Pöllänen P, Broberg E, Tapio V, Vahlberg T, Hukkanen V: Herpesviruses in brains in Alzheimer's and Parkinson's diseases. Ann Neurol 2003, 54(2):267-271.

38. Lang PO, Govind S, Aspinall R: Reversing T cell immunosenescence: why, who, and how. Age (Dordr) 2013, 35(3):609-620.

39. Pawelec G: Hallmarks of human "immunosenescence": adaptation or dysregulation? Immun Ageing 2012, 9(1):15.

40. Solana R, Tarazona R, Aiello AE, Akbar AN, Appay V, Beswick M, Bosch JA Campos C, Cantisán S, Cicin-Sain L, Derhovanessian E, Ferrando-Martínez S, Frasca D, Fulöp T, Govind S, Grubeck-Loebenstein B, Hill A, Hurme M, Kern F, Larbi A, López-Botet M, Maier AB, McElhaney JE, Moss P, Naumova E, Nikolich-Zugich J, Pera A, Rector JL, Riddell N, Sanchez-Correa B, et al: CMV and Immunosenescence: from basics to clinics. Immun Ageing 2012, 9(1):23.

41. Fülöp T, Larbi A, Pawelec G: Human T cell aging and the impact of persistent viral infections. Front Immunol 2013, 4:271.

42. Olsson J, Wikby A, Johansson B, Löfgren S, Nilsson BO, Ferguson FG: Age-related change in peripheral blood T-lymphocyte subpopulations and cytomegalovirus infection in the very old: the Swedish longitudinal OCTO immune study. Mech Ageing Dev 2000, 121(1-3):187-201.

43. Wikby A, Ferguson F, Forsey R, Thompson J, Strindhall J, Löfgren S, Nilsson BO, Ernerudh J, Pawelec G, Johansson B: An immune risk phenotype, cognitive impairment, and survival in very late life: impact of allostatic load in Swedish octogenarian and nonagenarian humans. J Gerontol A Biol Sci Med Sci 2005, 60(5):556-565.

44. Hadrup SR, Strindhall J, Køllgaard T, Seremet T, Johansson B, Pawelec G, Thor Straten P, Wikby A: Longitudinal studies of clonally expanded CD8 T cells reveal a repertoire shrinkage predicting mortality and an increased number of dysfunctional cytomegalovirus-specific T cells in the very elderly. J Immunol 2006, 176(4):2645-2653.

45. Buchholz VR1, Neuenhahn M, Busch DH: CD8+ T cell differentiation in the aging immune system: until the last clone standing. Curr Opin Immunol 2011, 23(4):549-554.

46. Stein M: Future directions for brain, behavior, and the immune system. Bull N Y Acad Med 1992, 68(3):390-410.

47. Gordon S: Do macrophage innate immune receptors enhance atherogenesis? Dev Cell 2003, 5(5):666-668.

48. Lynch MA: The impact of neuroimmune changes on development of amyloid pathology; relevance to Alzheimer's disease. Immunology 2014, 141(3):292-301.

49. Jimenez S1, Baglietto-Vargas D, Caballero C, Moreno-Gonzalez I, Torres M, Sanchez-Varo R, Ruano D, Vizuete M, Gutierrez A, Vitorica J: Inflammatory response in the hippocampus of PS1M146L/APP751SL mouse model of Alzheimer's disease: age-dependent switch in the microglial phenotype from alternative to classic. J Neurosci 2008, 28(45):11650-11661.

50. Gallagher JJ, Finnegan ME, Grehan B, Dobson J, Collingwood JF, Lynch MA: Modest amyloid deposition is associated with iron dysregulation, microglial activation, and oxidative stress. J Alzheimers Dis 2012, 28(1):147-161.

51. Okello A, Edison P, Archer HA, Turkheimer FE, Kennedy J, Bullock R, Walker Z, Kennedy A, Fox N, Rossor M, Brooks DJ: Microglial activation and amyloid deposition in mild cognitive impairment: a PET study. Neurology 2009, 72(1):56-62.

52. Schuitemaker A1, Kropholler MA, Boellaard R, van der Flier WM, Kloet RW, van der Doef TF, Knol DL, Windhorst AD, Luurtsema G, Barkhof F, Jonker C, Lammertsma AA, Scheltens $P$, van Berckel BN: Microglial activation in Alzheimer's disease: an (R)-[ $\left.{ }^{11} \mathrm{C}\right] \mathrm{PK} 11195$ positron emission tomography study. Neurobiol Aging 2013, 34(1):128-136.

53. Wang $X$, Zhu M, Hjorth E, Cortés-Toro V, Eyjolfsdottir H, Graff C, Nennesmo I, Palmblad J, Eriksdotter M, Sambamurti K, Fitzgerald JM, Serhan CN, Granholm AC, Schultzberg M: Resolution of inflammation is altered in Alzheimer's disease. Alzheimers Dement 2014, S1552-5260(14):00030-00032.

54. Monson NL, Ireland SJ, Ligocki AJ, Chen D, Rounds WH, Li M, Huebinger RM, Munro Cullum C, Greenberg BM, Stowe AM, Zhang R: Elevated CNS inflammation in patients with preclinical Alzheimer's disease. J Cereb Blood Flow Metab 2014, 34(1):30-33

55. Streit WJ, Xue QS, Tischer J, Bechmann I: Microglial pathology. Acta Neuropathol Commun 2014, 2(1):142.

56. Licastro F, Morini MC, Davis LJ, Malpassi P, Cucinotta D, Parente R, Melotti C, Savorani G: Increased chemiluminescence response of neutrophils from the peripheral blood of patients with senile dementia of the Alzheimer's type. J Neuroimmunol 1994, 51(1):21-26.

57. Licastro F, Pedrini S, Caputo L, Annoni G, Davis LJ, Ferri C, Casadei V, Grimaldi LM: Increased plasma levels of interleukin-1, interleukin-6 and alpha-1-antichymotrypsin in patients with Alzheimer's disease: peripheral inflammation or signals from the brain? J Neuroimmunol 2000, 103(1):97-102.

58. Licastro F, Morini MC, Polazzi E, Davis LJ: Increased serum alpha 1antichymotrypsin in patients with probable Alzheimer's disease: an acute phase reactant without the peripheral acute phase response. J Neuroimmunol 1995, 57(1-2):71-75.

59. Metti AL, Yaffe K, Boudreau RM, Ganguli M, Lopez OL, Stone KL, Cauley JA Change in inflammatory markers and cognitive status in the oldest-old women from the study of osteoporotic fractures. J Am Geriatr Soc 2014, 62(4):662-666.

60. Brosseron F, Krauthausen M, Kummer M, Heneka MT: Body fluid cytokine levels in mild cognitive impairment and Alzheimer's disease: a comparative overview. Mol Neurobiol 2014, 50(2):534-544.

61. Hermida AP, McDonald WM, Steenland K, Levey A: The association between late-life depression, mild cognitive impairment and dementia: is inflammation the missing link? Expert Rev Neurother 2012, 12(11):1339-1350.

62. Zhao SJ, Guo CN, Wang MQ, Chen WJ, Zhao YB: Serum levels of inflammation factors and cognitive performance in amnestic mild cognitive impairment: a Chinese clinical study. Cytokine 2012, 57(2):221-225.

63. Gironi M, Borgiani B, Farina E, Mariani E, Cursano C, Alberoni M, Nemni R, Comi G, Buscema M, Furlan R, Grossi E: A global immune deficit in Alzheimer's disease and mild cognitive impairment disclosed by a novel data mining process. J Alzheimers Dis 2014, [Epub ahead of print]

64. Lurain NS, Hanson BA, Martinson J, Leurgans SE, Landay AL, Bennett DA, Schneider JA: Virological and immunological characteristics of human 
cytomegalovirus infection associated with Alzheimer disease. $J$ Infect Dis 2013, 208(4):564-572.

65. Shoemark DK, Allen SJ: The microbiome and disease: reviewing the links between the oral microbiome, aging, and Alzheimer's disease. $J$ Alzheimers Dis 2014, [Epub ahead of print].

66. Sparks Stein P, Steffen MJ, Smith C, Jicha G, Ebersole JL, Abner E, Dawson D 3rd: Serum antibodies to periodontal pathogens are a risk factor for Alzheimer's disease. Alzheimers Dement 2012, 8(3):196-203.

67. Loos BG: Systemic markers of inflammation in periodontitis. J Periodontol 2005, 76(11 Suppl):2106-2115.

68. Chiba-Falek O, Linnertz C, Guyton J, Gardner SD, Roses AD, McCarthy JJ, Patel K: Pleiotropy and allelic heterogeneity in the TOMM40-APOE genomic region related to clinical and metabolic features of hepatitis C infection. Hum Genet 2012, 131(12):1911-1920.

69. Rivera MF, Lee JY, Aneja M, Goswami V, Liu L, Velsko IM, Chukkapalli SS, Bhattacharyya I, Chen H, Lucas AR, Kesavalu LN: Polymicrobial infection with major periodontal pathogens induced periodontal disease and aortic atherosclerosis in hyperlipidemic ApoE(null) mice. PLoS One 2013, 8(2): $\mathrm{e} 57178$

70. Fu P, Wang AM, He LY, Song JM, Xue JC, Wang CQ: Elevated serum ApoE levels are associated with bacterial infections in pediatric patients. $J$ Microbiol Immunol Infect 2014, 47(2):122-129.

71. Bell RD, Winkler EA, Singh I, Sagare AP, Deane R, Wu Z, Holtzman DM, Betsholtz C, Armulik A, Sallstrom J, Berk BC, Zlokovic BV: Apolipoprotein E controls cerebrovascular integrity via cyclophilin A. Nature 2012, 485(7399):512-516.

doi:10.1186/s12979-014-0022-8

Cite this article as: Licastro et al: The 21 st century epidemic: infections as inductors of neuro-degeneration associated with Alzheimer's Disease. Immunity \& Ageing 2014 11:22.

\section{Submit your next manuscript to BioMed Central and take full advantage of:}

- Convenient online submission

- Thorough peer review

- No space constraints or color figure charges

- Immediate publication on acceptance

- Inclusion in PubMed, CAS, Scopus and Google Scholar

- Research which is freely available for redistribution 